Anna Jakomulska, Bogdan Zagajewski, Anna Traut

\author{
APPLICATION OF FIELD REMOTE SENSING TECHNIQUES \\ FOR VEGETATION INVESTIGATION. \\ CASE STUDY OF SIWICA GLADE RESERVE
}

\title{
INTRODUCTION
}

Environmental research constitutes a complex analysis of environment, often carried out by a team of individuals specializing in particular aspects and components of environment like vegetation, soils, hydrography, etc. Detailed information on each of system components is synthesized and crosscorrelated to obtain a global, complex view on the processes determining the state of the researched site. At large scales (detailed research) an in-depth research of biotic components of environment is commonly used to derive conclusions about functioning of the whole ecosystem. This inference can be successfully applied in natural areas of limited human impact, where vegetation acts as an indicator of all the other constituents of the environment. On the other hand, biochemical components of vegetation are essential parameters controlling many environmental processes (e.g. nutrient cycles, carbon fluxes). Estimates of biophysical vegetation characteristics are also required for many operational applications like agricultural resource management or net primary production assessment. Recent developments in computer science, Geographic Information Systems and remote sensing enabled and extended possibilities of interdisciplinary inference and became important in monitoring and management of environment.

Remote sensing is particularly suited to mapping and analysis of vegetation and land cover - which in moderate and humid climates constitute the primary objects visible on aerial and satellite imagery. Vegetation indices derived from remotely sensed data like NDVI, enabled the creation of global biophysical databases, used in current generation of global climate models (Loveland et al., 1991; Sellers et al., 1996). Other parameters, like structural canopy parameter LAI allow for development of leaf and canopy radiative transfer models, used in an in-depth analyses of radiation interception and photosynthesis, precipitation interception, evapotranspiration, etc.

Currently, spaceborne, airborne and field remote sensing provide a wide toolbox allowing measurement of environmental features (e.g. vegetation 
communities, plant species) with great detail. The latter however, allows for greater precision and hence a large-scale research. It is expected, that a dynamic evolution of high-resolution, hyperspectral satellite sensors will soon provide data in a large coverage, allowing to extrapolate field point measurements to large areas. Environmental monitoring often requires fast-delivered, up-to-date data, which can not be collected from extensive areas using field campaign methods. This gap can be filled using integrated methods of field and spaceborne remote sensing techniques. In anticipation of the new generation satellite imagery (e.g. Hyperion sensor registering 220 bands, already placed on orbit of EO-1 satellite), we provide an introduction and theory behind field remote sensing techniques.

In this paper methodology of vegetation monitoring using field remote sensing techniques is presented. While based on data acquired from ground measurements rather than from satellite or aerial platforms, field remote sensing techniques are based on the same theory of electromagnetic radiation describing its contact with an object. Since remote sensing of vegetation is a central issue of this paper, we briefly introduce the process of interaction between sun light and plants in the next section. Spectral signatures of vegetation, being the primary source of plant and vegetation analysis are presented and analysed. We further focus on description and exemplification of spectral indices developed for derivation and analysis of indicators of plant and vegetation community condition, which can be used to infer both their state (e.g. stress) and further extended to derive conclusions on environmental condition. A relation between parameters derived from remote and direct measurement is shown.

In the discussion we focus on advantages of field remote sensing investigation techniques over conventional laboratory and field methods. We conclude with a short description of a complexity and interdisciplinarity of interaction between scene and radiation which is at the heart of remote sensing.

The methodology is presented on the example of a field campaign carried out in Siwica Glen Reserve, located within Bolimowski Landscape Park. The area has been chosen due to its unique ecological values and planned recultivation in the nearest future. The researched area is located within an extensive forest clearing dominated by meadow communities developed along soil humidity gradient. The area is under management of State Forests National Forest Holding, Forest Inspectorate in Skierniewice and Direction of Bolimowski Landscape Park. Formerly dominated by muck soils and covered by wet meadows and peat, it is proposed that the area is turned back to its primeval state. The area has been designated to be subjected to an extensive melioration project leading to re-development of muck soils. Melioration, being a long-term process affecting all parts of ecosystem may be non-reversible. Hence, a proper recognition and documentation of the state of the environment before and monitoring after the application of these practices must be carried out. In this study we research condition of three 
meadow communities currently dominating Siwica Glen Reserve: tufted hair grass community (Deschampsietum caespitosae), bulrush community (Scirpetum silvatici) and silverweed community (Potentilletum anserinae).

\section{INTRODUCTION TO REMOTE SENSING PRINCIPLES}

Remote sensing is based on registration of electromagnetic radiation reflected, transmitted and/or emitted by an object which allows to detect, identify and analyse the object of interest. Spectral signature, being a function of reflectance over wavelength, results from both physical and chemical properties of objects and is the main source of information used for object identification. Knowledge of an object compounds content, its structure as well as recognition of wavelengths at which those elements absorb sunlight, allows object identification with high accuracy - both in the field, as well as from aerial and satellite platforms.

Spectral signature of a plant is distinctive and variable with wavelength (Figure 5), its characteristic absorption features being a direct result of its physiological process. Plant reflectance in visible part of electromagnetic spectrum is determined by pigments content. Photosynthesis is based on conversion of radiation absorbed in blue and red parts of electromagnetic spectrum to energy (Fig. 6). Chlorophyll $a$ is the main factor in photosynthesis while chlorophyll $b$ plays a secondary function, supporting chlorophyll $a$ in light absorption. Maximum of absorption for chlorophyll $a$ is noted for (440 and $663 \mathrm{~nm}$ ) while chlorophyll $b$ absorption is shifted towards longer waves in blue wavelenths $(470 \mathrm{~nm})$ and towards shorter wavebands in red $(647 \mathrm{~nm})$. Carotenoids' role is to protect chlorophyll from photooxidation and thylakoid membranes from destruction resulting from excess sun radiation. High content of carotenoids is noted for plants subjected to extensive sun radiation (e.g. alpine species). Quantity of carotenoids increases also with plant senescence. Carotenoid absorption spectrum shows a maximum in the blue portion of the electromagnetic spectrum, with a maximum shifted towards longer waves in comparison with chlorophyll absorption in this part of electromagnetic spectrum. Furthermore, carotenoid absorption spectrum lacks a peak in a red portion of electromagnetic spectrum which is characteristic for chlorophyll absorption spectrum. Other pigments such as xanthophylls and anthocyanins can also contribute to absorption of visible radiation (Gamon et al., 1992; Barton and North, 2001).

Precise measurement of spectral reflectances in the blue part of electromagnetic spectrum from satellite orbits is troublesome due to high diffusion, absorption and reflection of short-wave radiation in the atmosphere. Red band can be however used as an indicator of the condition of photosynthesising apparatus of a plant. Plants absorb as much as $80-90 \%$ of radiation in red band, hence only $10-20 \%$ of radiation reaching plant is reflected and detected 
by a sensor. Low-energy, infrared radiation is useless for plants: in fact its excess, if absorbed, would have to be transformed into heat, requiring a very intensive 'cooling' system. Most of near-infrared radiation (NIR) is multiply scattered between air and cell walls of leaf mesophyll resulting in high reflectance values (approximately 50\%) (Maas and Dunlap, 1989; Gausman, 1974). High reflectance characterises plants in good condition, while lower reflectance can be attributed to water, heat or nutrient stress. However, the reflectance depends on the species and the characteristic structure of a leave (e.g. coniferous species have lower reflectance than deciduous ones). Reflectance in middle-infrared wavebands (mid-IR) is characterized by values lower than reflectance in the NIR. Mid-IR reflectance is controlled by internal leaf structure i.e. mesophyll tissue (Knipling, 1970; Wolley, 1971), being a result of physiological processes like evaporation. At characteristic water absorption bands at $1.43,1.95$ and $2.2 \mu \mathrm{m}$ reflection in Mid-IR is attenuated by leaf water content. Increased reflectance in Mid-IR for a particular species may suggest dehydration of plant leaves.

The most prominent feature in the reflectance spectrum of vegetation is the so called "red edge" spanning wavebands within $670-760 \mathrm{~nm}$. A unique contrast in reflectance is due to the sharp increase of reflectance from chlorophyll absorption in the red region and scattering by the plant cells in the NIR part of electromagnetic spectrum. The position of the red edge is determined by inflection wavelength, which is defined as the wavelength where the rate of increase of reflectance is the maximum. The wavelength position of the red edge is known to be a parameter which is sensitive to plant development: phenology and health status (Guyot et al., 1992).

The process of automated object identification is based on comparison of detected spectral signatures of an object with either in situ measurements carried out at the time of satellite or aerial image acquisition or a spectral library of the objects of interest. The latter method, although preferable and widely used in geological exploration, poses many problems in vegetation research. The main reason stems from the fact that spectral characteristics of plants experience large annual changes that correspond to various stages of phenology during the growing season. Additionally, apart from biophysical properties of a leaf many factors influence spectral composition of light reflected from vegetation. Among others these include: species composition and coverage, plant leaves arrangement, plant height, soil humidity, etc. Due to this fact, vegetation research using satellite or aerial remote sensing does not replace or eliminate field campaigns. The latter can be however reduced to a minimum, including measurements carried out in representative polygons or points. Field data can be further extrapolated to large areas using satellite or aerial imagery (Chen et al., 2002).

In addition to spectral characteristics of vegetation, there exists a wide range of supporting indices used in vegetation research, like: NDVI (Tucker, 1979), SR (Tucker, 1979), WDVI (Clevers, 1988), SAVI (Huete, 1988), MSAVI (Qi et al., 1994), NLI and NLI2 (Goel and Qin, 1994), AVI (Plummer et al., 
1994), PRI (Barton and North, 2001). The principal of a vegetation index is to define a simple relationship between the reflectance measured by a sensor in particular wavelengths and parameter directly characterizing a plant (e.g. condition of a photosynthesising apparatus, efficiency of evapotranspiration process) or vegetation stand (like biomass or canopy structure). Normalized Difference Vegetation Index (NDVI) is one of the most commonly used indices and will be used in this study:

$$
\mathrm{NDVI}=(\mathrm{IR}-\mathrm{R}) /(\mathrm{IR}+\mathrm{R})
$$

NDVI is based on the unique character of plant spectral signatures and uses reflectance at two wavelengths located within the "red edge": near infrared (IR) and red (R). It relates difference in NIR and red reflectance and normalizes it by its sum. Difference between NIR and red reflectance can be used as an indicator of both photosynthesis and tissue structure of plants, hence can be used as a measure of vegetation condition. Normalization of the difference by the divisor forces the value to range between -1 and 1 , at the same time minimizing the influence of signal noise. NDVI may be related to canopy photosynthetic capacity because of its relation to green biomass. Vegetation in a good condition is characterized by high values of NDVI, reaching above $0.6-0.7$. NDVI values oscillating around and below 0.5 suggest either early or senescent stage of plant growth or stress related to factors other than phenology. Lower values $0-0.2$ are noted for soils, while negative - for water.

Other commonly used biophysical vegetation characteristics which can be directly derived from remote sensing measurements include, among others: LAI (Leaf Area Index), fAPAR (fraction of Absorbed Photosynthetically Active Radiation) and plant-air temperature difference. Detailed definitions and measurement principles of these characteristics will be introduced in subsequent paragraphs.

\section{STUDY SITE: SIWICA GLADE RESERVE}

Siwica Glade Reserve is located in Nieborów gmina in Łódź voivodship. According to Physico-Geographical Regionalization of Poland (Kondracki, 1978), the polygon of research is located within boundaries of the mesoregion: Łowicz-Błonie Plain, that is situated in macroregion: Central Masovia Lowland, sub-province: Central Polish Lowlands and province: Central European Lowlands. The study site comprises of a large forest clearing located within extensive forest complex of Bolimowski Landscape Park (Fig. 1). Bolimów Forest $\left(170-180 \mathrm{~km}^{2}\right.$ ) is the second largest (after Kampinos National Park) forest in Western part of Masovia region (Olaczek, 1999), protected since 1986. In 1997, Siwica Glade was recognized as an important part of the forestmeadow ecosystem and embodied within a protection zone of a reserve. Being a result of extensive forest clearing activities carried out in the region since 1564, Siwica covers a relatively large area ( 68.55 ha). Forest clearing delivered 


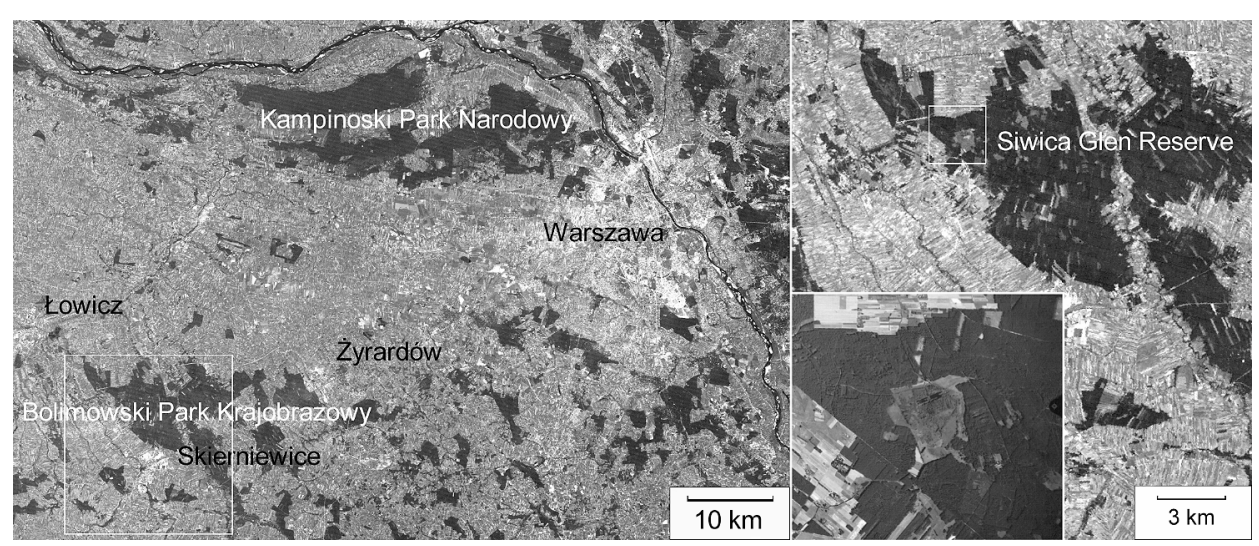

Fig. 1. Location of Bolimowski Landscape Park and Siwica Glen Reserve study site on Landsat TM 5 satellite image and the aerial image.

many products like: wood, bark, potash, charcoal, birch tar and the like, sustaining living of large communities. Some of the cleared forests were left over and allowed to re-grow at the pace of natural succession. However, at more humid areas with high level of ground water, further human activity including pasturage and hay-making led to development of meadow and peat communities. Land use in the area exerted however low impact, which, adding to the stable environmental conditions, promoted establishment of a extensive, stable and floristically rich vegetation communities (Kucharski and Pisarek, 1997).

Siwica Glade is located at $99 \mathrm{~m}$ a.s.l. and constitutes a depression within alluvial cone, created by glacier activity during the Middle Polish (Warta) glaciation (Klajnert, 1982). The area is drained by several forest streams. Flat topography supports development of muck soils. Currently, excess water is collected by a system of drain ditches, carrying water to the west of the area. Soils are mainly organic, including peat soils and peat-mud soils, dominated by sedge peat and sedge-moss peat. In drier areas muck soils and muckmineral soils prevail. All soils have acidic reaction (Kucharski, 1995).

Climatic conditions of the area are characterised by high yearly sun insolation, being one of the highest in the country scale. It amounts to $86.3 \mathrm{kcal} / \mathrm{cm}^{2}$, while country maximum noted in Sandomierz is $87.8 \mathrm{kcal} / \mathrm{cm}^{2}$ (Koziejowa and Koziej, 1996). Daily insolation reaches a high yearly average of 4.6 hours, with the maximum insolation in September. Precipitation in the area decreases from south-west (Strzelno: $640 \mathrm{~mm}$ ) to north-east (Skierniewice, located in the proximity of Siwica: $523 \mathrm{~mm}$ ). Evaporation from the areas has been assessed to reach 500 to $520 \mathrm{~mm}$ yearly in the open space (Koziejowa and Koziej, 1996) leading to a significant water deficit in soil. The warmest month is July $\left(18^{\circ} \mathrm{C}\right)$ and coldest - January $\left(-2.9^{\circ} \mathrm{C}\right)$. Mean velocity of dominant westerly winds reaches $3.5 \mathrm{~m} / \mathrm{s}$ (Misiewicz-Śnieszko, 1982). 
Being a large peat-meadow area, Siwica Glade Reserve is unique in the country scale. Flora of the park amounts to 225 plant species, including 9 protected and 4 placed on the endangered species list (in Poland). Several species are also considered to be endangered of extinction from the area of central Poland (Kucharski, 1995). As many as 25 plant communities can be identified in the area, including peat, meadow, aquatic, shrub and rush communities. Rush communities developed in overgrowing water bodies and ditches, as well as wetlands, including communities like: reed rush (Phragmitetum comunis), reed-mace community (Typhaetum angustifoliae), mud sedge community (Caricetum acutiformis) and other sedge communities like: Caricetum gracilis and Caricetum rostratae. Of particular importance to the ecosystem are meadow and perennial weed communities: blue moor grass community (Molinietum caeruleae medioeuropeum) and also marsh cranesbill community (Filipendulo - Geranietum). Meadow harvesting, grazing and draining lead to introduction of common species and disappearance of typical communities in the area. In result, the reserve is dominated by abundant common vegetation communities, devoid of unique plant species like: tufted hair grass community (Deschampsietum caespitosae), Yorkshire fog community (Holcetum lanatii) and locally appearing patches of bulrush community (Scirpetum silvatici). Northern part of the glade is dominated by a silverweed community (Potentilletum anserinae).

Floral diversity, relative remoteness from human settlements and existence of water bodies lead to establishment of an important refuge for waterfowl and many amphibians and reptiles. The Reserve is also abundant in invertebrates and mammal species. Until 1627 the area supported the last in the World herd of aurochs (Bos taurus primigenius).

Due to a methodological character of this study, the research area has been restricted to the northern part of Siwica Glade Reserve, where the following, dominant vegetation communities were investigated in detail: Deschampsietum caespitosae, Scirpetum sylvatici and Potentilletum anserinae.

Deschampsietum caespitosae Horvatić 1930. Class: Molinio-Arrhenatheretea (all meadows), Order: Molinietalia (wet meadows), Alliance: Alopecurion pratensis (mainly floristically rich meadows, used for hay-making, after: Kucharski, 1999). Deschampsietum caespitosae (further referred to as Dc, Fig. 2) is currently the most common meadow community in Poland. Dominance of $D c$ in the ecosystem often indicates soil moisture disturbances in the habitat. Deschampsia caespitosa - tufted hair grass is resistant to humidity changes, hence quickly gains dominance over other meadow plants, superseding them from many vegetation communities. The species is characteristic for Molinietalia, and can be found in many plant communities. However, if dominant in the community, it is recognized as Deschampsietum caespitosae. Due to its fragility to grazing and low mowing, dominance of Deschampsia caespitosa species indicates a lack of management practices like hay-making and pasturage (Kucharski, 1999). Two variants of the $D c$ community are identified: semi-wet and wet, the researched patches of $D c$ belong to the latter 


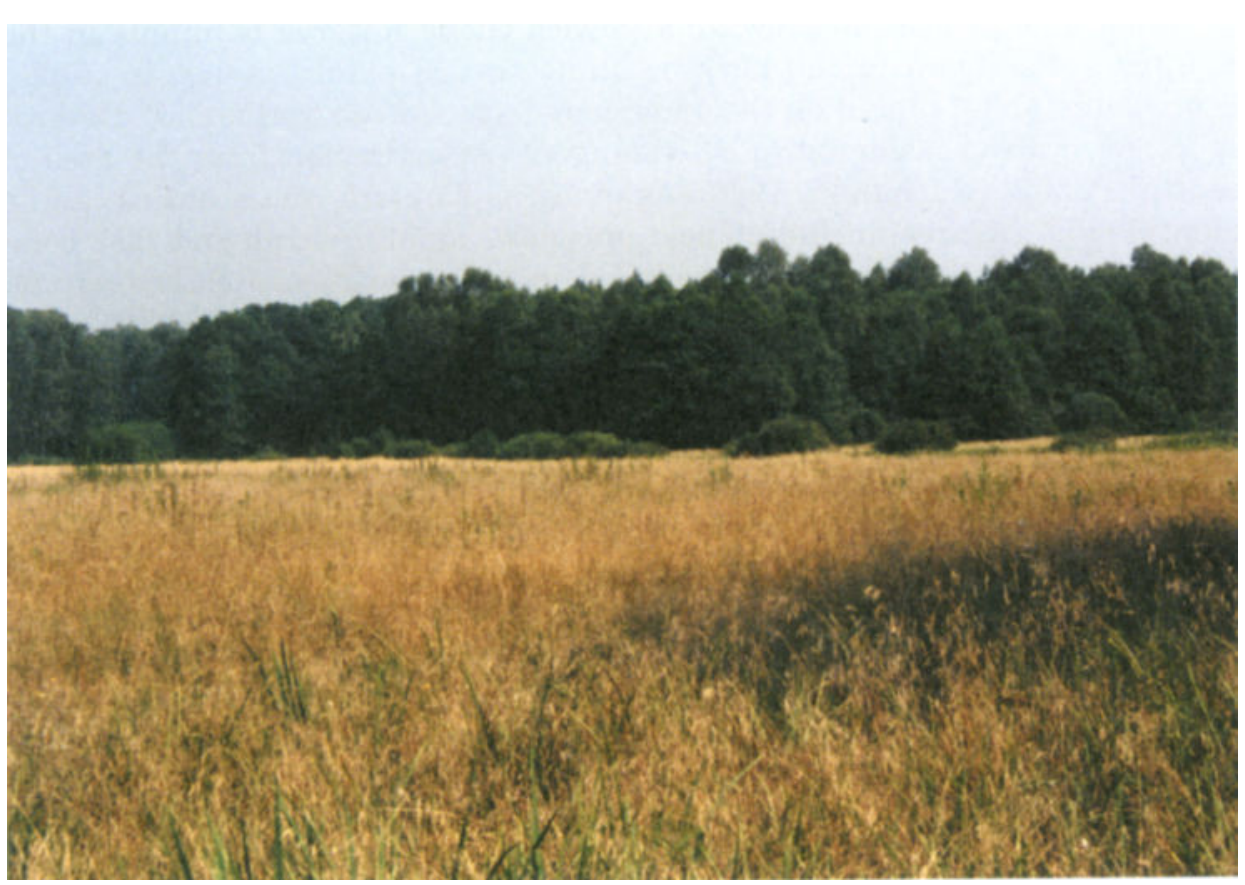

Fig. 2. Deschampsietum caespitosae community.

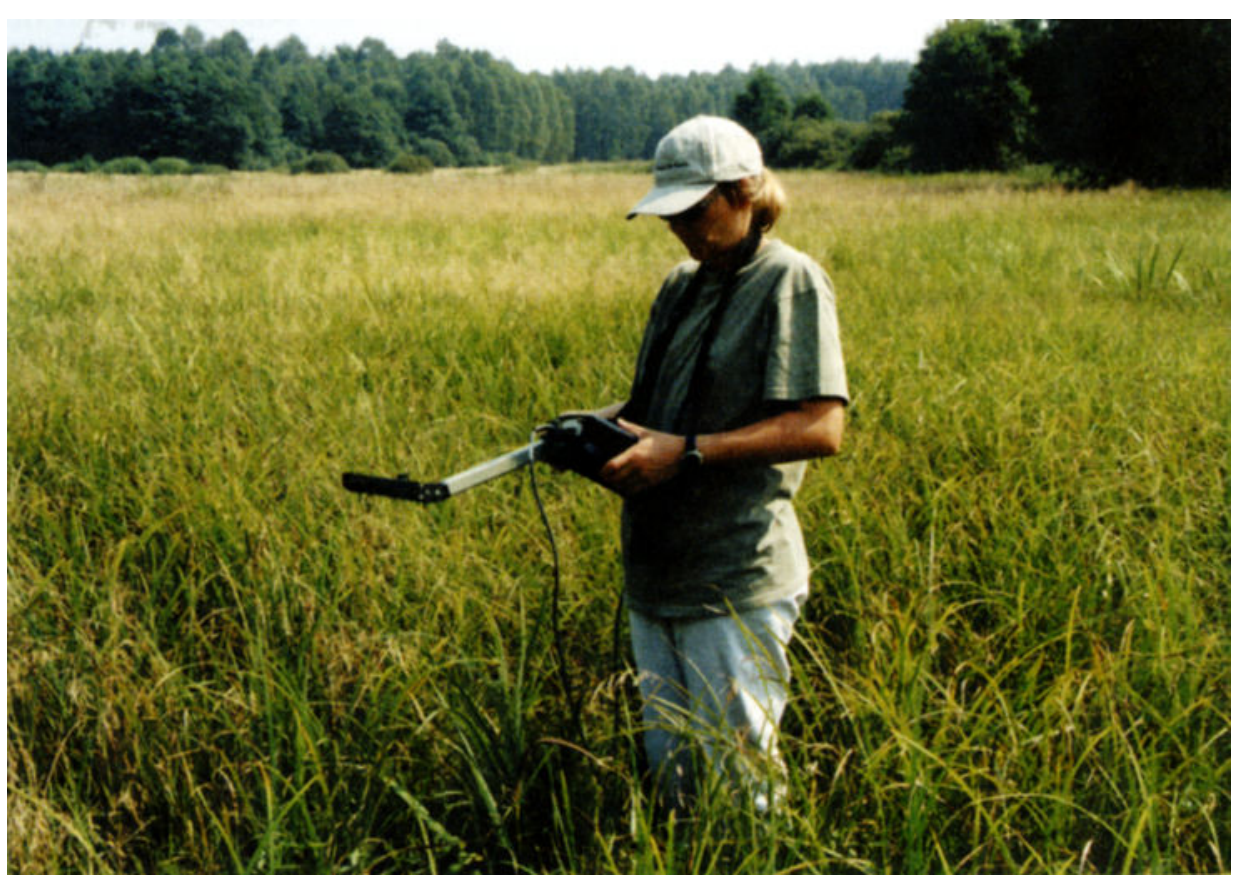

Fig. 3. Scirpetum sylvatici community. 


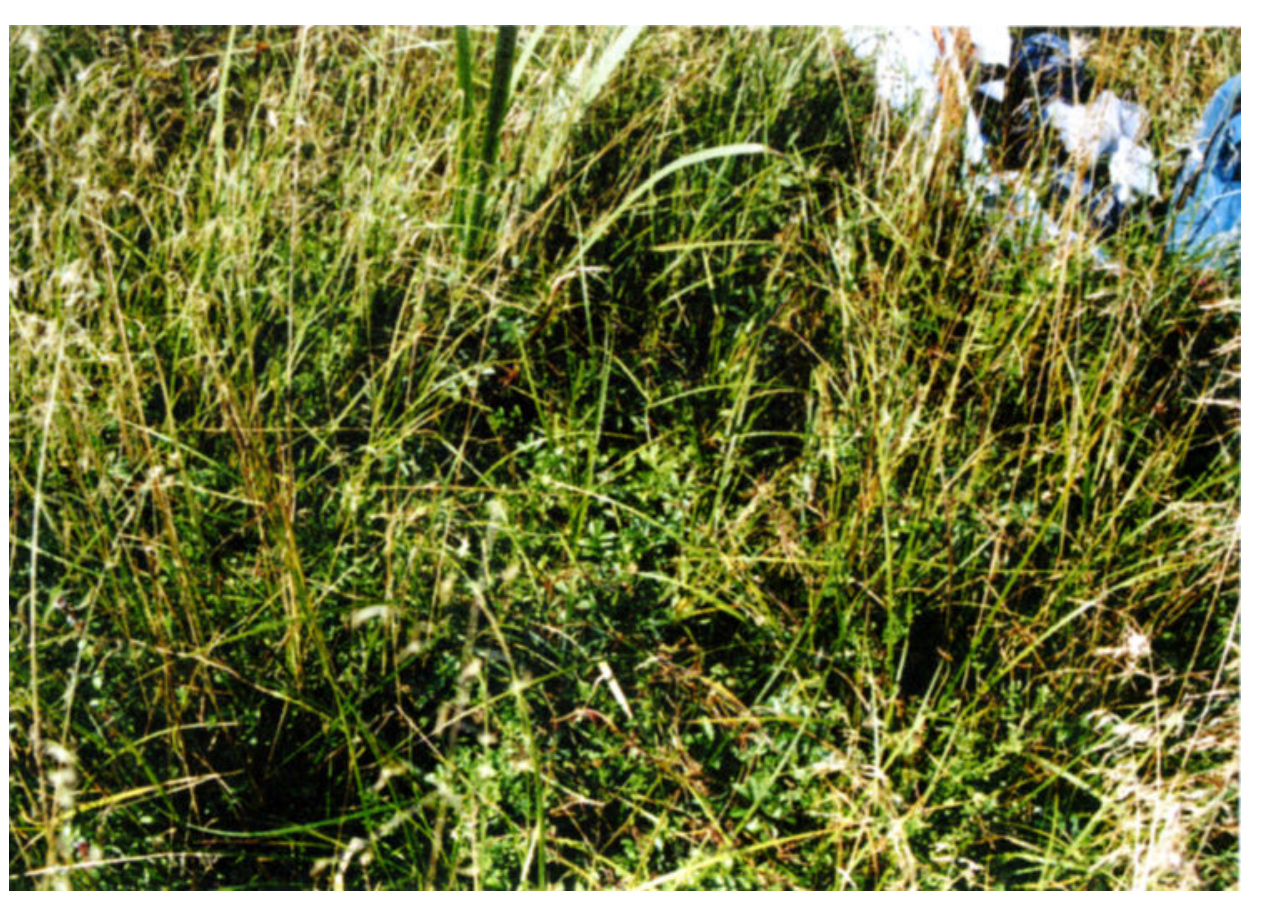

Fig. 4. Potentilletum anserinae community.

variant. The studied sites were characterised by a pronounced dominance of Deschampsia caespitosa with interspersed Ranunculus repens, Lotus corniculatus, Filipendula ulmaria, Lysimachia nummularia and Lythrum salicaria. The researched $D c$ stands can be described as floristically poor, in comparison with $D c$ patches recorded in other parts of Bolimów Large Forest (Traut, 2000). Average height of researched $D c$ communities reached $80 \mathrm{~cm}$.

Scirpetum sylvatici Knapp, 1946. Class: Molinio-Arrhenatheretea, Order: Molinietalia, Alliance: Calthion (mainly wet pastures after: Kucharski, 1999). Scirpetum sylvatici community (further referred to as $S s$, Fig. 3) is dominated by bulrush Scirpus sylvaticus. It is one of the most floristically poor meadow communities, developing at water-logged areas, particularly at local depressions on mineral-organic soils. It commonly forms small patches among other meadow communities. Its economic exploitation is insignificant due to low quality of produced hay: dry leaves of bulrush form narrow and sharp stripes. The researched patches of $S s$ were typical for the area of Bolimów Large Forest: floristically poor with a dominance of bulrush and a small admixture of stinging nettle (Urtica dioica), Lythrum salicaria, Lysimachia vulgaris, and Epilobium hirsutum. Average height of researched $S s$ communities was $60 \mathrm{~cm}$.

Potentilletum anserinae (Rapaics 1927) Pass. 1964. Class: Molinio-Arrhenatheretea, Order: Trifolio-Agrostietalia stoloniferae (mainly extensively used hay meadows), Alliance: Agropyro-Rumicion crispi (mainly meadows of little 


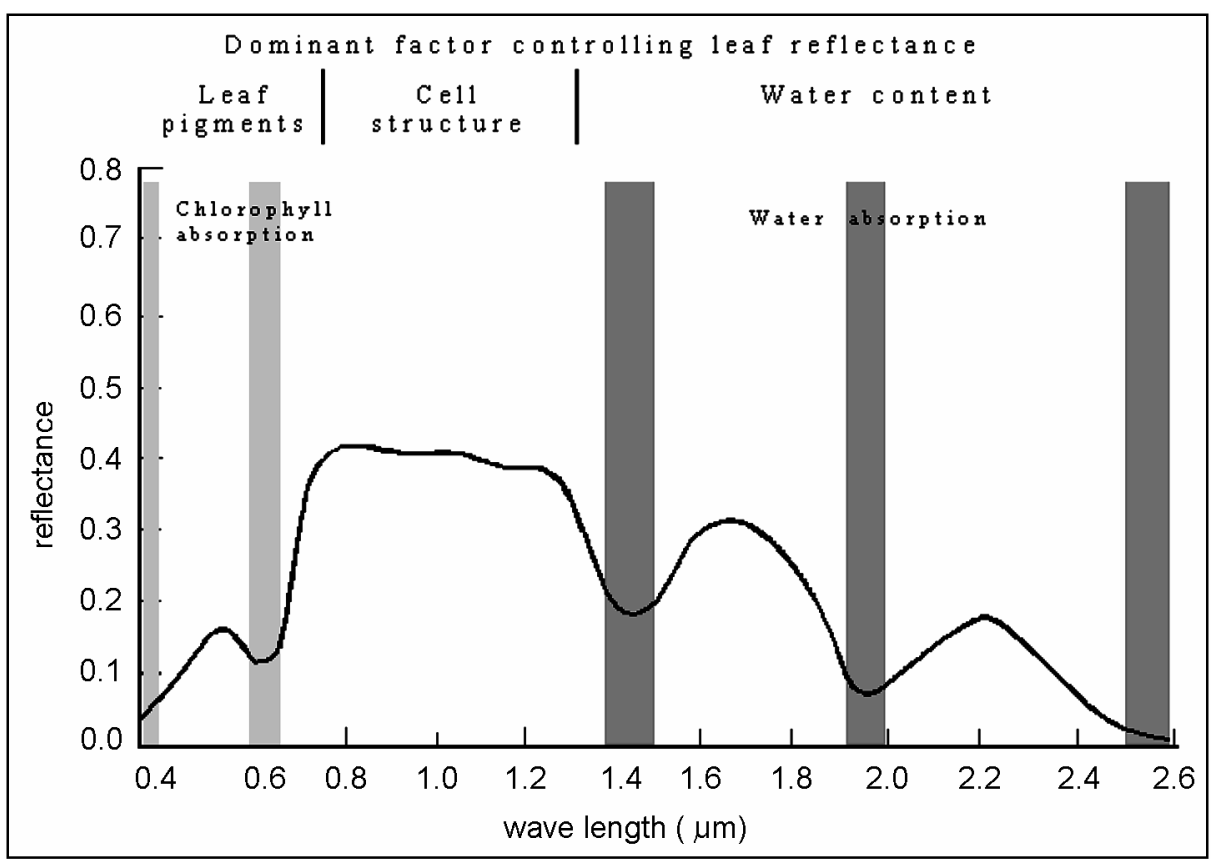

Fig. 5. Spectral signature of plants.

economic utility, after: Kucharski, 1999). The community is named after a popular meadow species - silverweed (Potentilla anserina), characteristic for Alliance: Agropyro-Rumicion crispi. Identification of Potentilletum anserinae community (further referred to as $P a$, Fig. 4) is commonly based on the dominance of silverweed. $P a$ is commonly found on "goose pastures" former sites of goose and duck pasturage. Currently the community is rare, due to changes in pasturage use and poultry farming. The community is unique in Central Poland and its existence in Siwica Glade can be attributed to the presence of nearby forest-guard's lodge. $P a$ community is accompanied by a steady, but small participation of: Deschampsia caespitosa, Plantago lanceolata, Juncus effusus and Geum rivale. On average, $\mathrm{Pa}$ communities reached the height of $50 \mathrm{~cm}$.

\section{METHODS: REMOTE SENSING TECHNIQUES FOR VEGETATION CONDITION ANALYSIS}

Field remote sensing measurements on the study site of Siwica Glen Reserve were carried out on $21^{\text {st }}$ and $31^{\text {st }}$ August 2001. The year has been exceptionally good for vegetation development and the state of the researched vegetation was good. No vegetation in poor condition or under stress has been detected. Four sets of measurements characterizing different aspects of vegetation and its habitat condition were carried out at both sites: 


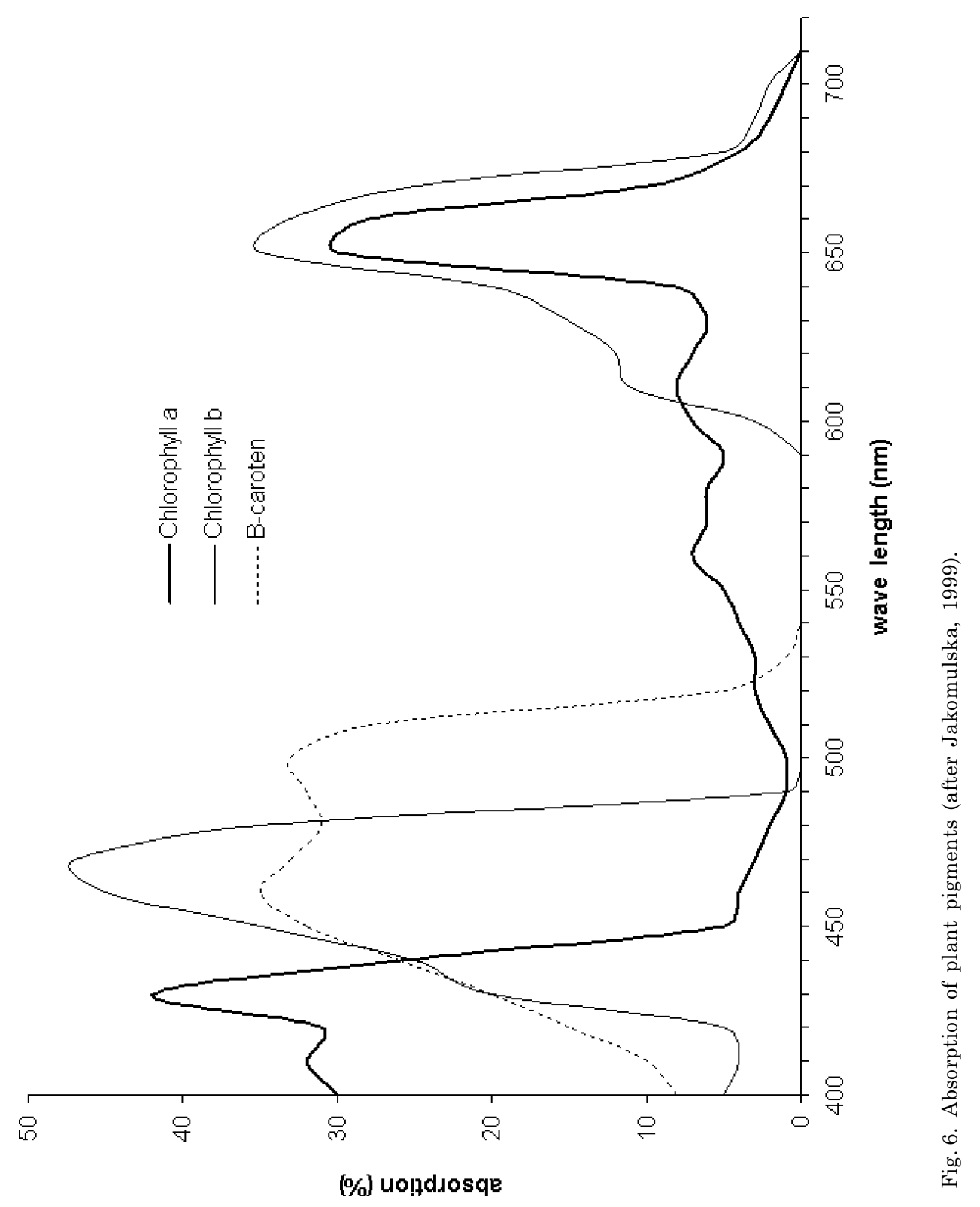


- spectroradiometer measurements allowing for recognition of spectral signatures of researched plants and communities and NDVI derivation,

- Leaf Area Index measurements characterising biomass, plant coverage compactness and vegetation canopy structure,

- Accumulated Photosynthetic Active Radiation balance allowing yield analysis,

- leaf and air temperature and soil moisture allowing for heat and water balance analysis and evapotranspiration inference.

All measurements were made at midday (10-14 hours) at good solar conditions. Full insolation was observed with insignificant coverage of high level Cirrocumulus clouds. The latter, located at the outer part of the sky hemisphere did not have influence on the measurements. To ascertain statistically significant sample, multiple measurements were made for each of the researched communities, each of which was investigated at six different test polygons located in different parts of Siwica Glade Reserve. Measurements at each site were made in series, within which number of individual measurements varied with the variability of the measured parameters and will be given for each method below.

\section{Spectrometric measurements}

Spectrometric measurements were carried out using field spectrometer SP1 (Fig. 7b) which simultaneously registers reflection in four bands: green $(510-590 \mathrm{~nm})$, red $(610-690 \mathrm{~nm})$, infrared $(710-790 \mathrm{~nm})$ and infrared $(860-$ $940 \mathrm{~nm}$ ). Mean widths of used filters are about $80 \mathrm{~nm}$. Spectral and radiometric characteristics of the detector have been designed to simulate signal detected by Landsat 4 MSS (Rataj, 1998, 1999). The angle of view of SP1 spectrometer equals $14^{\circ}$ and for measurements made at a height of $1 \mathrm{~m}$, size of the Instantaneous Field of View (IFOV) responds to about $0,625 \mathrm{~m}^{2}$ (Fig. 7a). Measured spectral signatures characterise hence vegetation communities, not individual plants (Jakomulska, 1999). However, since the researched communities were dominated by one species of a compact and full coverage, we can approximate individual plant signatures by the measured ones.

One measurement set consists of a pair of two measurements: the object of research and a white calibration screen (a circular lambertian surface covered with $\mathrm{BaSO}_{4}$ ). Assuming 100\% reflection of the calibration screen, a ratio of the two measurements represents spectral reflectance of an object. Each of the objects was measured in a series consisting of 10 samplings. Preprocessing of the recorded values was based on a statistical analysis of the acquired data. In each series, measurements exceeding two standard deviations from the mean were excluded from further analysis. Further on, spectral reflectance depends on the intensity of radiation reaching the object. Although all measurements were carried out close to noon, at strong insolation conditions, some differences are noted. During the measurements of an object carried out in the four spectral bands, an additional measurement of incoming 


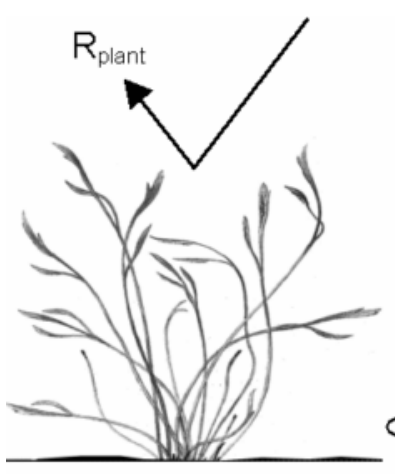

A

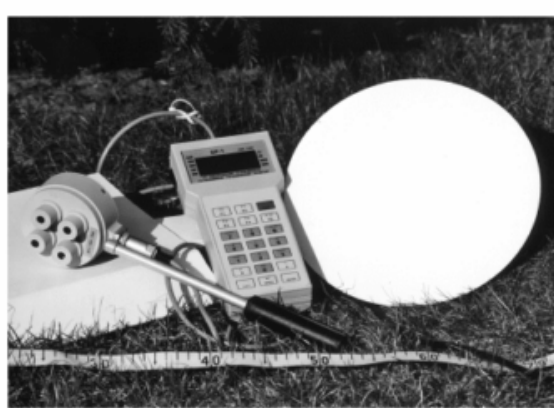

B

Fig. 7. A) Scheme of spectrometer measurements, B) Spectrometer SP1.

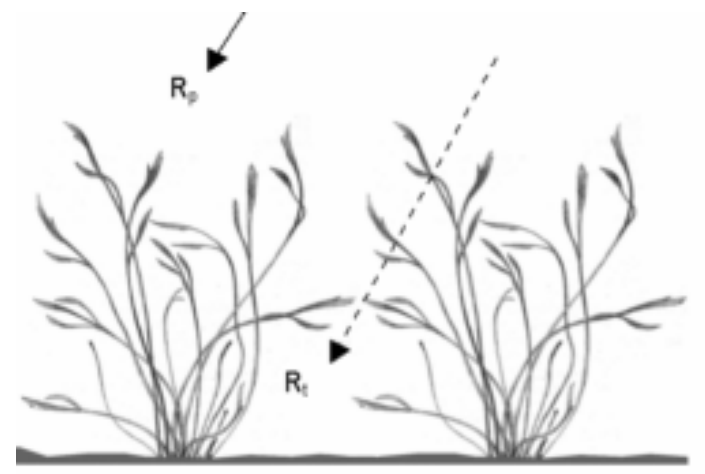

A

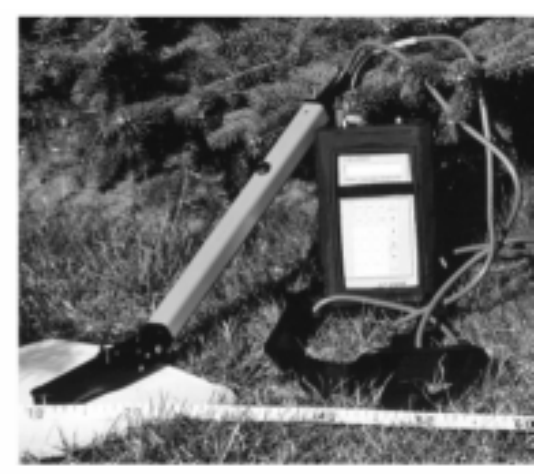

B

Fig. 8. A) Scheme of LAI measurements: measurement of sky brightness above the canopy and light transmitted measured below the canopy, B) LAI-2000 Plant Canopy Analyser.

solar radiation is made. The latter allows to monitor insolation changes due to solar zenith angle change and cloud cover and was later used to eliminate spectral reflectances acquired at lower radiation levels. Finally, means of spectral reflectances were used to derive spectral characteristics of researched communities and to calculate NDVI values.

\section{Survey of Leaf Area Index (LAI)}

Canopy structure, referring to the distribution of positions, orientations, areas and shapes of various plant organs plays a fundamental role in quantitative analysis of many physical and biological processes. Related to vegetation dynamics it can be used in research of nutrient cycles, radiation and precipitation interception, evapotranspiration, wind speed and turbulence, etc. (Welles and Norman, 1991; Chen et al., 2002). It can be also related 
to vegetation community characteristics including biomass and crop yield. Frequently used measures of canopy structure include: Leaf Area Index (LAI), foliage density and Leaf Angle Distribution Parameter. We further focus on presentation and analysis of LAI, which is a crucial parameter in growth models as well as an important factor affecting the reflectance from vegetation stands. LAI is defined as the area of leaves per unit ground surface area that the investigated community occupies (Chen and Black, 1992). Plant surface depends on plant coverage of the ground and arrangement of the leaves and branches. For a surface covered by vegetation in 100\%, LAI reaches higher values for multi-layer canopies. Hence a forest stand without brushwood has lower LAI index than the same forest stand with developed understory vegetation. For meadow and grassland communities, LAI varies with compactness of individual plants and leaf arrangement, reaching higher values when plants are compact and leaves are arranged vertically. For a particular biome type an optimal LAI value can be established: in too dense, compact vegetation canopies, lower vegetation stores and/or lower parts of plants receive little sunlight, hence production of the community is lower than optimal.

A special care must be taken while analysing plant species with varied compositional and structural differences between leaf side (adaxial and abaxial surfaces i.e. upper and lower, respectively) of leaves. In many plants (dorsiventral leaves) the upper surface (composed mainly of palisade tissue) is characterized by packed, upright elongated cells with many chloroplasts, while the lower surface (spongy mesophyll) is composed of less packed smaller cells. Leaf Angle Distribution parameter, varied for planophile and erectophile canopies must be further taken into account. These differences are significant as the relative direction of leaves with respect to the sensor influences reflection (Myneni and Ross, 1990).

Direct measurements of LAI using destructive field measurements are tedious, extremely labour-intensive, and often infeasible (e.g. for practical reasons in forests LAI measurements are limited to a few sample trees). Conventionally, LAI is measured by cutting off all plants (for meadow and herbal communities from an area of $0,25 \mathrm{~m}^{2}$ ) and measuring the area of their leaves and stems. Alternatively, indirect techniques based on estimation of LAI through remote sensing measurement of radiation penetrating through canopy can be used.

An indirect approach to LAI estimation is to utilise light interception measurements. Field remote sensing measurement of LAI is based on detection of diffuse part of radiation reaching the plant and transmitted through the canopy (measured above and below the canopy, respectively) (Fig. 8a). In this study measurements were made using LI-COR LAI-2000 Plant Canopy Analyser (Fig. 8b), which measures the radiation through a fish-eye lens. Measurements are made in the short part of electromagnetic radiation (below $490 \mathrm{~nm}$ ) to minimize the contribution of light scattered by foliage. The sensor consists of five photodiodes whose active surfaces are arranged in concentric 
rings, which allows to measure canopy gap fractions at various angles (Welles 1990), which is related to LAI. Each of the communities was measured with 3 samplings.

Comparison of measurements made at an experimental site of Szymbark using both traditional and remote sensing techniques (Fig. 9) as well as other research (Welles, 1990; Welles and Norman, 1991) indicate high correlation of results acquired using both methods. The relation is linear and assuring that direct LAI measurements can be successfully used as an alternative do direct LAI measurements.

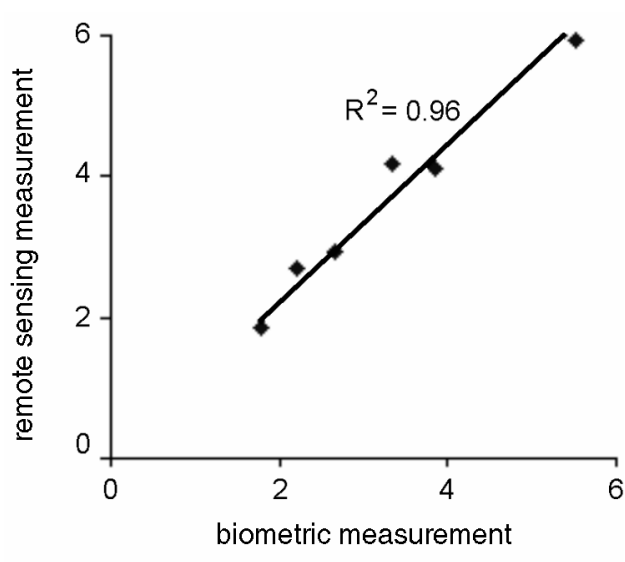

Fig. 9. Relationship between direct and indirect LAI measurements.

LAI is related to Leaf Angle Dis-

tribution Parameter describing distribution and orientation of foliage. This parameter influences the amount of radiation available for reception by plants (PAR, see below). Although critical for the proper understanding of canopy structure, its description is not covered in this paper.

\section{Measurements of Accumulated Photosynthetic Active Radiation}

Photosynthetically Active Radiation (PAR) is defined as radiation within $400-700 \mathrm{~nm}$ and represents portion of electromagnetic spectrum that is used by plants in photosynthesis process. Plants depend on sunlight to stimulate photosynthesis. In dense canopies, the amount of PAR available to understory plants and seedlings is a vital measurement in assessing the status of a vegetation stand. PAR measurements can be also used in assessing calculation and modelling of canopy structure (using the inversion canopy model developed by J. Norman).

Accumulated Photosynthetically Active Radiation (APAR) is a fraction of PAR, intercepted by plants for photosynthesis.

APAR measurement is based on measurement of the four radiation components: direct, photosynthetically active radiation reaching a plant (PAR0), radiation reflected from a plant $\left(\mathrm{PAR}_{\mathrm{c}}\right)$, radiation transmitted through leaves of plants $\left(\mathrm{PAR}_{\mathrm{t}}\right)$ and radiation reflected from ground $\left(\mathrm{PAR}_{\mathrm{s}}\right)(\mathrm{Fig}$. 10a). These four measurements are further used to derive amount of radiation absorbed by a plant, using a balance equation:

$$
\operatorname{APAR}=\left(\operatorname{PAR}_{0} \downarrow+\operatorname{PAR}_{\mathrm{s}} \uparrow\right)-\left(\operatorname{PAR}_{\mathrm{t}} \downarrow+\operatorname{PAR}_{\mathrm{c}} \uparrow\right)
$$

The up and down arrows indicate the direction of fluxes away and towards the surface, respectively. 


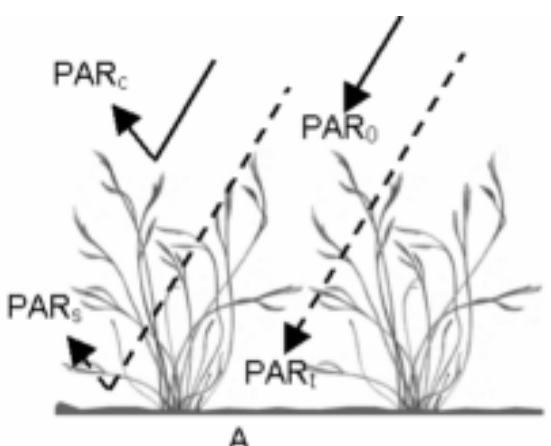

A

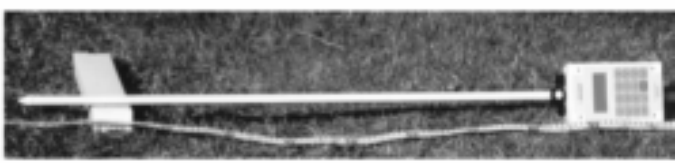

B

Fig. 10. A) Scheme of APAR measurements, B) AccuPAR instrument.

Ratio of absorbed radiation to the total amount of radiation reaching a plant constitutes a fraction of radiation absorbed by a plant and used in photosynthesis is called productivity index (fAPAR) (Asrar et al., 1989; Daughtry et al., 1992):

$$
\mathrm{fAPAR}=\mathrm{APAR} / \mathrm{PAR}_{0}
$$

Index of productivity can be further used to infer the condition of photosynthesising apparatus, and hence, the state of a plant. Stressed plants and senescent plants use a reduced amount of radiation in comparison to mature, vigorous ones.

Both energetic plant balance (APAR) and productivity were calculated in this study. Each of the communities was measured in a 3 measurements series. APAR was measured using AccuPAR instrument (Fig. 10b), constructed of 80 photodiodes of $1 \mathrm{~cm}$ length, operating in a PAR sampling mode. Partitioning of the probe into separate detectors allows to perform the measurement in sparse or clumped canopies, using only the selected detectors.

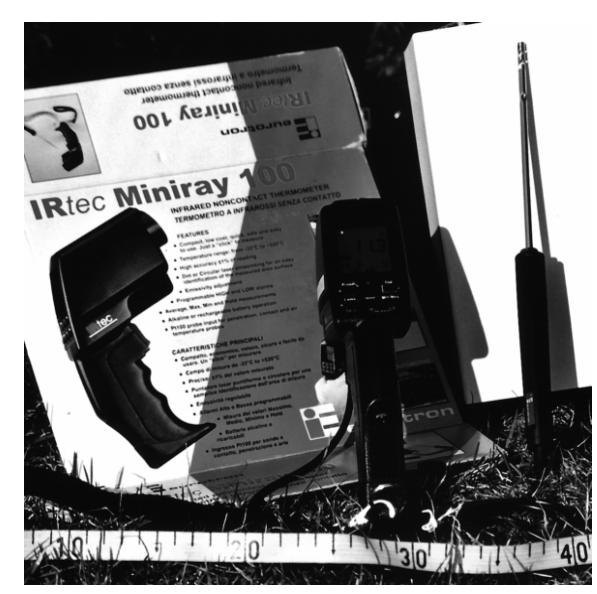

Fig. 11. Radometer iRtec MiniRay.

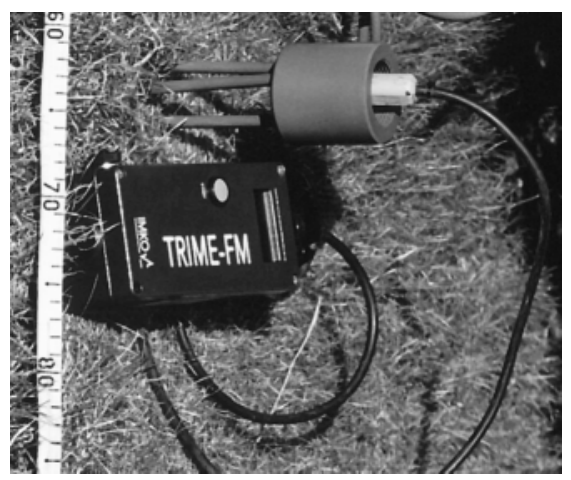

Fig. 12. Trime TDR probe. 


\section{Plant heat and water balance assessment}

Measurements of plant heat balance, represented by a difference of plant temperature $\left(t_{s}\right)$ and air temperature $\left(t_{a}\right)$ are used to infer heat and water management of plant, that is evapotranspiration. The process of evapotranspiration allows plants to cool down: for vigorous plants temperature difference $\mathrm{t}_{\mathrm{s}}-\mathrm{t}_{\mathrm{a}}$ is negative, provided water is available in the ground. Inadequate water supply decreases the evaporative heat loss from plants due to stomatal closure resulting in an increase in canopy temperature. Stressed plants can be identified by positive or close to zero $t_{\mathrm{s}}-\mathrm{t}_{\mathrm{a}}$ differences (Jackson et al., 1977; Jackson et al., 1987). Both plant and air temperature measurements were made with a radiometer iRtec MiniRay (Fig. 11). The basis of the measurement is detection of radiance in thermal infrared range of electromagnetic spectrum $(8-14 \mu \mathrm{m})$ and its conversion to temperature using Stefan-Boltzman equation. Each measurement was made with 5 pairs of $t_{\mathrm{s}}$ and $t_{\mathrm{a}}$ samplings. Data preprocessing was limited to derivation of mean temperatures and temperature differences $t_{\mathrm{s}}-\mathrm{t}_{\mathrm{a}}$.

As noted above, the process of evapotranspiration is conditioned by plant accessibility to water present in the ground. Hence, accompanying measurements of soil moisture were carried out using TRIME instrument (Time Domain Reflectometry with Intelligent Micromodule Elements) (Fig. 12), which measures volumetric soil moisture (Trime ${ }^{\circledR}$ Measuring Moisture Theory, 1997). The measurement is based on active remote sensing technique (microwave): an electromagnetic wave $(300 \mathrm{MHz})$ is sent along 3 sticks pressed into ground and measurement of time, within which the wave returns to the sensor is made. The measured time is related to the dielectric constant and to humidity of soil.

\section{Correlation of the field data}

Measurements made in the four sets of experiments are highly correlated since they all describe condition of plants and/or communities. It is often unsatisfactory to infer plant condition based solely on one of the above described indices. Hence, the final analysis was based on regression and analysis of all the measured indices.

Data acquired at Siwica reserve proves good condition of research vegetation, hence a dynamic range of the recorded values is narrow. To exemplify a full range of possible values and relations between the researched values an additional data set collected in June 2001 at the experimental study site of Field Research Station of Institute of Geography and Spatial Organization of Polish Academy of Sciences in Szymbark near Gorlice is used. The research measurements were conducted on meadows with dominance of Arrhenatherum elatius, Dactylis glomerata, Festuca pratensis, Phleum pratense and Poa pratensis. Plants were measured both at mature (fresh) and senescent stage (with many dry stems and leaves). Additionally, measurements of dry and wet soil were made. 


\section{RESULTS}

\section{Spectral properties of researched meadow communities}

Spectral signatures of researched communities: Deschampsietum caespitosae (Dc), Scirpetum sylvatici $(S s)$ and Potentilletum anserinae $(P a)$ are characteristic for grasses in good condition (Jakomulska, 1998; Kurnatowska, 1999; Zagajewski, 2000) (Fig. 13). Due to the fact that reflectance measurements were made by a spectrometer equipped in broad bands detector, the acquired reflectance is averaged across wide bands (approximately $80 \mathrm{~nm}$ ), and hence differences between detected signatures of the researched communities are not profound. However, some differences can be noted. Reflectance of $P a$ in red band is higher than those of two other communities. This suggests that plants of $P a$ community did not accumulate as much radiation for photosynthesis as plant dominants in the other two communities. Lower reflectance

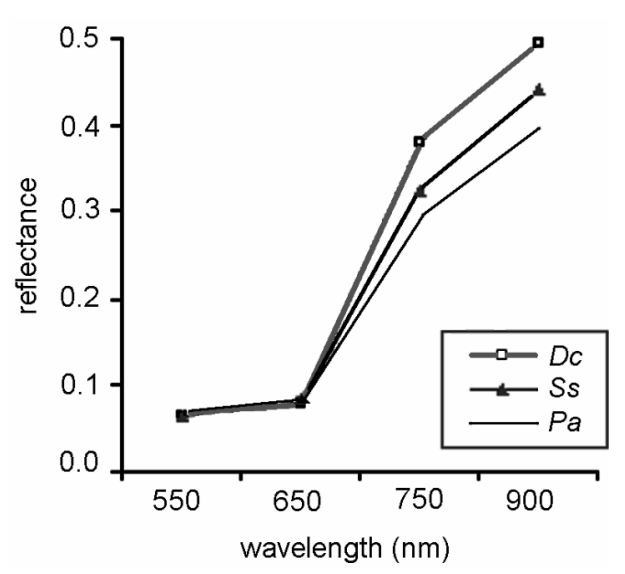

Fig. 13. Spectral signatures of researched communities.

A recorded range of NDVI is very narrow, oscillating between 0.65 and 0.75 indicating a good condition of the dominant species of researched communities. As shown on Figure 14b, some variability in NDVI was noted for same communities located at different sites, however a general trend is sustained. NDVI is lowest for $P a$ and highest for $D c$ (Fig. 14a), confirming that plants of the $P a$ community have already entered a repose state. This sequence of NDVI values supports the conclusions on plant condition derived from analysis of visible part of electromagnetic spectrum. 


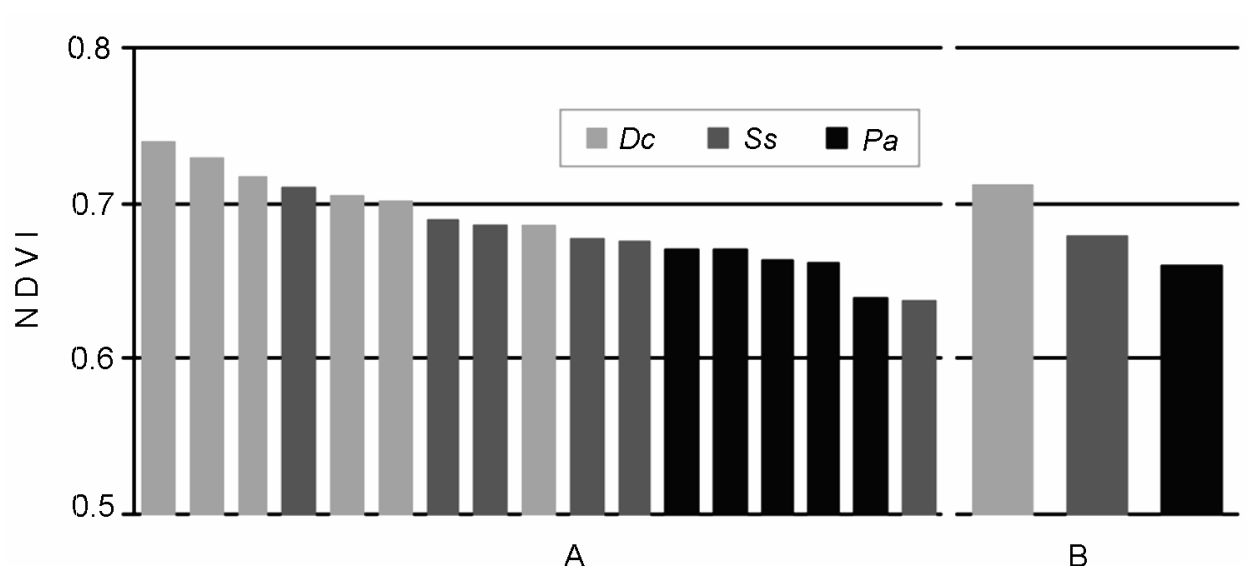

Fig. 14. NDVI A) for indvidual test sites, B) mean.

\section{Biomass and canopy structure analysis}

LAI index measured for all researched communities oscillates around an optimal value of LAI $\approx 4$ (Fig. 15a, 15b), while the highest values were noted for $P a$ (above $\mathrm{LAI}=6$ ), and lowest for $D c$ community (around LAI=3). Higher values noted for $P a$ community confirm visual observation of the community: high density and compactness. Due to high canopy density lower parts of plants, being in shade, received little sun radiation, hence we could assume that their photosynthetic productivity was lower than optimal. This result will be further confirmed.

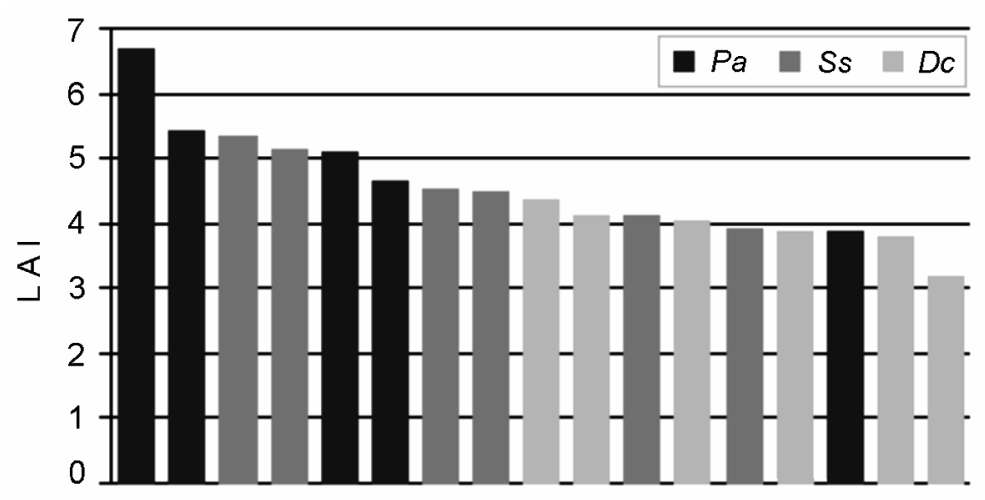

A

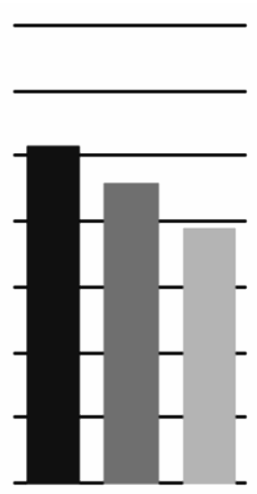

B

Fig. 15. LAI A) for indvidual test sites, B) mean.

\section{Condition of a photosynthesising apparatus}

Productivity defined as an $\mathrm{APAR} / \mathrm{PAR}_{0}$ ratio for all researched communities was very high (Fig. 16) and signifies that as much as $90 \%$ of sun radiation 


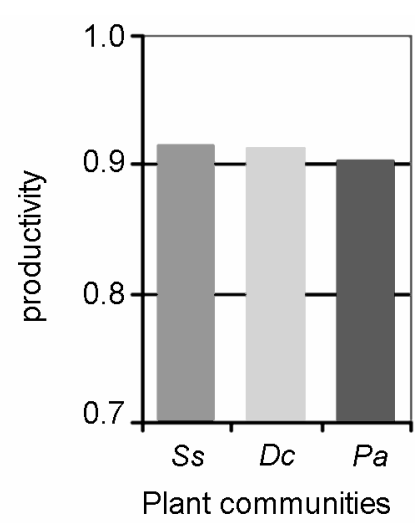

Fig. 16. Productivity. within the photosynthetic spectrum is absorbed by plants to sustain their growth. Differences between the three communities are at the verge of significance, however, it can be noted, that productivity of $P a$ is lowest. That supports above mentioned thesis: due to high density of plant canopy (LAI >4), not all parts of a plant are able to photosynthesise. Hence, in spite of a larger biomass, productivity of $P a$ community is lower than productivity of the other two communities, where productivity efficiency is appropriate to the size of photosynthesising apparatus.

\section{Plant heat and water balance}

Temperature differences between plant and air temperature for all plant communities were negative, which indicates good performance of the process of evapotranspiration of the plant species building the communities. Since air temperatures at the time of the measurements reached $30^{\circ} \mathrm{C}$, the efficiency of the cooling system was of particular importance. At all sites soil moisture was abundant and oscillated around $20-25 \%$ of soil volume (Table 1 ).

Table 1.

Mean air and plant temperatures and volumetric soil moisture

\begin{tabular}{|c|c|c|c|c|}
\hline $\begin{array}{c}\text { Plant } \\
\text { community }\end{array}$ & $\mathrm{t}_{\mathrm{s}}\left({ }^{\circ} \mathrm{C}\right)$ & $\mathrm{t}_{\mathrm{a}}\left({ }^{\circ} \mathrm{C}\right)$ & $\mathrm{t}_{\mathrm{s}}-\mathrm{t}_{\mathrm{a}}\left({ }^{\circ} \mathrm{C}\right)$ & $\begin{array}{c}\text { moisture } \\
(\% \mathrm{Vol})\end{array}$ \\
\hline$D c$ & 26,5 & 31,1 & $-4,6$ & 23,3 \\
\hline$P a$ & 24,3 & 30,4 & $-6,2$ & 22,8 \\
\hline$S s$ & 26,2 & 32,1 & $-6,0$ & 25,2 \\
\hline
\end{tabular}

\section{Correlations between measures of vegetation condition}

The index NDVI is routinely used in estimating surface parameters such as LAI, fAPAR, vegetation fractional cover and others, although studies have shown that the form of the relationship varies from linear to curvilinear (Asrar et al., 1992; North, 2002; Purevdorj, 1998; Eklundh, 2001). In this section a correlation between NDVI and LAI and NDVI and temperature difference is shown, while productivity is related to LAI. In the study carried out at Siwica, similar canopies and status of researched vegetation stands resulted in a very narrow range of NDVI and LAI values. Although the results indicate a good state of researched vegetation, a small dynamic range of obtained data prohibits presentation and exemplification of relations between NDVI, 


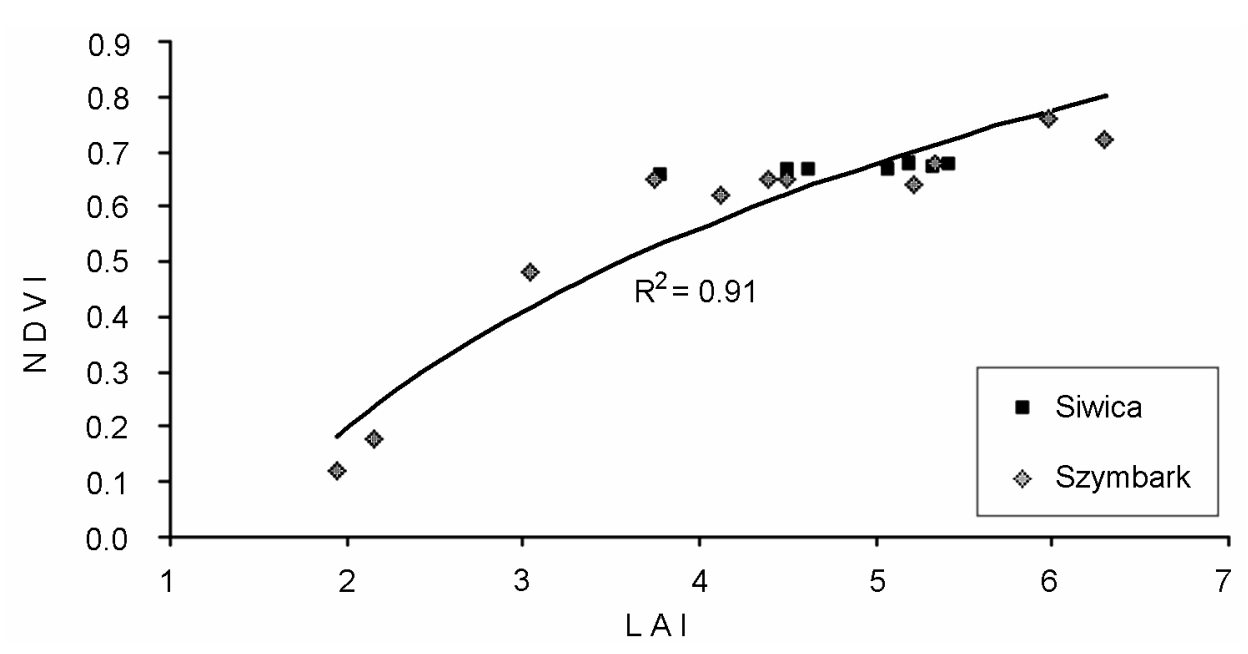

Fig. 17. Relationship between NDVI and LAI (based on measurements carried out at Siwica and Szymbark test sites).

LAI and other measured parameters. To present NDVI/LAI relation for a full range of possible values, an additional data set collected at Szymbark experimental test site was used, where a wide range of LAI and NDVI values was noted (Fig. 17). Apart from fresh meadow communities, dry stands were measured. The measurements of the latter produced low NDVI and LAI values indicating poor condition or senesced state of the stands.

NDVI is positively related to LAI (Fig. 17). The observed relationship corresponds to literature reports (Clevers, 1989; Myneni et al., 1997) and is logarithmic, with NDVI saturation point close to $\mathrm{LAI}=4.7$ at NDVI values oscillating between $0.6-0.7$. The regression between the two variables shows that significance of this relation is strong $\left(R^{2}=0.91\right)$. Measurements recorded at Szymbark cover a wide range of values while measurements taken at Siwica test site occupy the point of inflection on the logarithmic plot and oscillate around the optimal value of LAI. As discussed above, for each of biomes there exists an optimal LAI, at which photosynthesis is at its peak (e.g. LAI $\approx 4$ for meadows and herbs). At high LAI values (> LAI=4), NDVI typically saturates, which indicates that with further increase of biomass per area unit, total photosynthesis from that unit does not increase. For assessment of LAI above value of 5, Dąbrowska-Zielińska (1995) proposed an empirical model relating linearly and indirectly LAI to NDVI, with the use of soil moisture estimate.

A relation between LAI and productivity is presented on Figure 18. Increase of LAI leads to an increase of absorption of PAR. As expected, with an increase of biomass (estimated by LAI), an increase of productivity is noted, however, again a saturation is noted at high LAI values. The relation between the parameters is best described by a logarithmic function with a very high correlation $\left(\mathrm{R}^{2}=0.99\right)$. Again, Siwica measurements occupy the "optimal" 


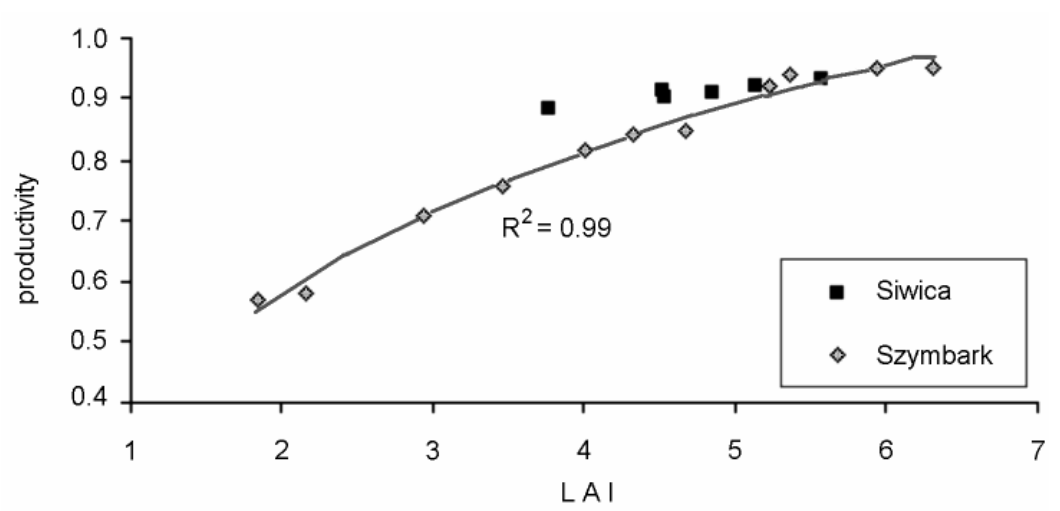

Fig. 18. Relationship between productivity and LAI (based on measurements carried out at Siwica and Szymbark test sites).

position on the plot (optimal LAI, very high productivity), while measurements from Szymbark test site record also lower values.

Vegetation biomass can be related both to LAI and NDVI indices (Dabrowska-Zielińska, 1995; Gruszczyńska, 1992). The relation has to be however evaluated each time experimentally as it depends on study site and sensors. Furthermore, application of different LAI-spectral relationships for different biomes like meadows, coniferous forests, deciduous forests etc. has been recommended (Chen and Cihlar, 1996; Chen et al., 2002). More sophisticated, physics-based models relating LAI and NDVI have also been proposed (Chen and Leblanc, 1997).

Finally, NDVI was plotted against $t_{\mathrm{s}}-\mathrm{t}_{\mathrm{a}}$ difference, relating NDVI to evapotranspiration efficiency (for soils: transpiration efficiency). To introduce the principles and present a complete picture we use additional data collected at Szymbark test site, where two distinct land cover types characterized by a varied soil moisture were measured. In Szymbark, measurement sites were located at: two grassland communities: fresh and senescent, and two bare arable grounds, moist and dry. These four land cover types are mutually distinct, each occupying a specific place on the chart relating NDVI to temperature difference (Fig. 19). Soils are located at a lower part of the chart as NDVI measured for soils is low (below 0.2). Difference between dry and moist soil is distinct: positive and negative temperature differences are noted (lowerright and lower-left chart corner), respectively. Vegetation occupies upper part of the chart: NDVI of a dry grassland oscillated at a low level of 0.5, while NDVI of a grassland growing at humid soil exceeded value of 0.6 , indicating good status of a photosynthesising apparatus. Negative temperature difference of a fresh community signify that evapotranspiration is at its best (upperleft chart corner), while positive differences noted for the senescent community prove that evapotranspiration ceased (upper-right chart corner).

Results of the analysis carried out at Siwica Reserve are less contrasting: all three types of researched vegetation communities reach high values of 


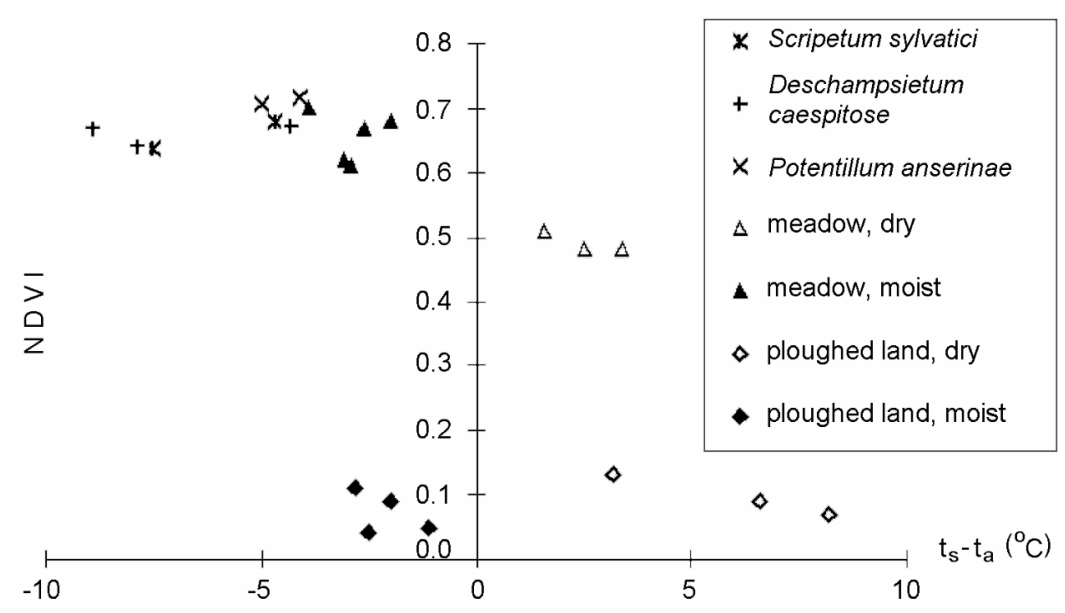

Fig. 19. Relationship between NDVI and plant-air temperature difference $\left(t_{\mathrm{s}}-\mathrm{t}_{\mathrm{a}}\right)$ (based on measurements carried out at Siwica and Szymbark test sites).

NDVI and negative values of temperature difference, located at the upperleft corner of a graph, suggesting that both photosynthesis and evapotranspiration performed well. A noticeable gradient of temperature differences may be noticed, where the differences increase from $D c$, through $S s$ and to $P a$. This results correlates to the humidity of the habitat: vegetation growing at very humid habitats evaporate less, since temperature difference is low (van de Griend and Owne 1993). High temperature difference noted for Pa community can be related both to drier soil conditions and to larger biomass, in comparison to the other two communities.

Summarizing, the health and status of the researched communities at Siwica Glen Reserve, based both on visual inspection and remote sensing field measurements was assessed to be good. Although in the maturing stage of the phenological period, plants were still photosynthesising and evaporating. Small, but recognizable decrease of the condition of $P a$ stands has been noted and was attributed to the senescence of dominant plants of the community. A decrease of NDVI and productivity may be also attributed to dense canopy and LAI values above the optimal threshold for meadow communities.

\section{DISCUSSION}

In this study we have presented and exemplified remote sensing instrumentation and field measurement techniques for analysis of vegetation condition. While correlating with traditional methods of field data collection, remote sensing techniques can be recommended due to several advantages over direct methods of field and laboratory techniques within plant physiology, biometrics and/or phytosociology. First, remote sensing techniques are fast and easy to use. Each of the measurements lasts only few seconds which 
allows to collect large and statistically significant datasets in short time and with little time, effort and money. Each of the instruments can be carried by one operator. Due to the speed of data acquisition and processing as well as to the fact that measurements are acquired directly, the results of the measurements are available right after the measurement is made, that is in the field (e.g. there is no need to dry vegetation to derive biomass). The advantage of direct measurement is a fact that there is no loss of information in data transport, processing, etc. (e.g. decay of pigments with time and temperature, loss of plant material on laboratory pots and due to cumulating and propagating errors). Furthermore, remote sensing data is obtained by a non-destructive approach (e.g. plant pigment content measurement is possible without the necessity to cut the leaves and plant biomass assessment - without cutting plants). More importantly, some of the measurements introduce new characteristics of vegetation, that were not available before or difficult to measure directly. As an example a measurement of Leaf Area Index provides information on both biomass (which can be measured using traditional, destructive biometric methods) and canopy structure, which so far was described only qualitatively (in a linguistic scale). So far, mathematical modelling of canopy geometry has been very basic and not applicable to complex canopies. Another example is APAR, which directly measures the amount of radiation absorbed by plants for photosynthesis. Other techniques, not discussed in this paper in detail (e.g. plant canopy structure characteristics) can be derived from field remote sensing techniques.

However, although a relative technical ease of field remote sensing techniques methods has been stressed, a few constraints must be presented.

Parameters obtained using remote sensing techniques are commonly expressed in values and units that are not used in direct techniques. Hence, it takes a lot of experience to interpret the values and to relate them to physical values (e.g. relating dimensionless LAI to biomass expressed in tons per hectare). In many applications, where a direct measurement is not required, expert knowledge allows to interpret the collected data. However, at cases where absolute values are required, a relationship between remote sensing indices and physical values measured at a field must be found empirically. It is recommended to use a hybrid model of research where conventional field measurements accompany remote sensing techniques to establish empirical relationships between the two: e.g. destructive LAI measurements can be used to establish relationship with more easily measured LAI derived from measurements based on light interception. The advantage of incorporation of remote sensing is a fact, that laborious field techniques may be applied at a limited number of test sites, while large data sets can be collected using remote sensing techniques. Finally, this model of data gathering, incorporating both traditional and remotely sensed techniques, is commonly further correlated and extrapolated to extensive study sites using aerial and satellite imagery (Chen et al., 2002).

It must be stressed, that full explanation of environmental conditions and processes inferred from remote sensing analysis of plants and vegetation com- 
munities requires expert and interdisciplinary knowledge within plant physiology, phytosociology, environmental sciences as well as physics (e.g. optics, electromagnetic laws and theories), remote sensing, statistics and mathematics (modelling). To understand the intensity of reflected light of a vegetation stand one needs to judge and/or model several biotic properties (e.g. plant tissue composition, leaf optical properties, vegetation community composition and coverage, canopy structure) as well as other factors like: geometry of viewing direction (angles of detector-sun-object system influencing illumination and Bidirectional Reflectance Distribution Function), radiative transfer (e.g. to model atmospheric influence on the radiation on its pathway: light diffusion and absorption), geometry of the acquired imagery (geometric referencing, extent, spatial resolution) and many others.

A considerable and growing interest and need to understand these effects and relate them quantitatively to environmental processes has led to development of a range of accurate and sophisticated models of leaf reflectance and transmittance (Jacquemoud et al., 1996) and of radiative transfer within plant canopies (Myneni et al., 1989; Goel, 1988; Goel and Thompson, 2000). To provide continuous vegetation monitoring these models should take account of both diurnal and annual changes of vegetation. Other models commonly based on data derived from multi-spectral remotely sensed data include heat and water balance modelling for evapotranspiration estimation (Jackson 1985). It has been found that the intake of atmospheric carbon dioxide by the plants for photosynthesis is proportional to the water transpired, and several studies have successfully related crop yields to evapotranspiration. Other studies proved the utility of vegetation indices based on temperature to relate positively and closely to crop yield. Modelling crop yield in Poland using indices derived from AVHRR satellite imagery produced only 4\% difference between estimates produced by the Central Statistical Office - however predictions acquired from remotely sensed data were obtained 4 weeks before harvest, while statistical data was delivered long after the harvest (Dabrowska-Zielińska et al., 2002). Same indices were used to estimate crop growth conditions, including drought monitoring. Although information on drought is readily obtained from meteorological observations, modelling of data obtained from remote sensing provides continued coverage of bio-climatic conditions, while measurements made at meteorological stations are obtained in point locations only.

In the context of a large number of input parameters in many environmental models, remote sensing can play a unique and essential role in environmental research, provided that we can relate remote sensing measurements to biochemical characteristics of objects in a reliable and operational way. Dynamic development of high ground resolution, hyperspectral sensors placed at satellite orbit (imaging spectroscopy form space), is a promise that a detailed environmental data will be collected in future with increased speed and frequency. Integration of remote sensing techniques with traditional techniques of field research provides means to monitor environment at a realtime pace. 


\section{REFERENCES}

Asrar G., Myneni R.B., Kanemasu E.T., 1989. Estimation of plant-canopy attributes from spectral reflectance measurements. In: Asrar G. (ed.) Theory and applications of optical remote sensing. Wiley, New York, 252-293.

Asrar G.F., Myneni R.B., Choudhury B.J., 1992, Spatial heterogeneity in vegetation canopies and remote sensing of absorbed photosynthetically active radiation: a modelling study, Remote Sensing of Environment, 41, 85-103.

Barton C.V.M., North P.R.J., 2001, Remote Sensing of canopy light use efficiency using the photochemical reflectance index, Model and sensitivity analysis, Remote Sensing of Environment, 78, 264-273.

Chen J.M., Black T.A., 1992. Defining leaf area index for non-flat leaves. Plant, Cell and Environment 15:421-429.

Chen J.M., Cihlar J., 1996, Retrieving leaf area index of boreal conifer forests using Landsat TM images, Remote Sensing of Environment, 55, 153-162.

Chen J.M., Pavlic G., Brown L., Cihlar J., Leblanc S.G., White H.P., Hall R.J., Peddle D.R., King D.J., Trofymow J.A., Swift E., Sander van der J., Pellikka P.K.E., 2002. Derivation and validation of Canada-wide coarse-resolution leaf area index maps using high-resolution satellite imagery and ground measurements, Remote Sensing of Environment, 80, 165-184.

Chen J.M., Leblanc S., 1997, A 4-scale bidirectional reflection model based on canopy architecture, IEEE Transactions on Geoscience and Remote Sensing, 35, 1316-1337.

Clevers J.G.P.W., 1988, The derivation of a simplified reflectance model for the estimation of leaf-area index, Remote Sensing of Environment, 25 (1), 53-69.

Clevers J.G.P.W., 1989, The application of a weighted infrared-red vegetation index for estimating leaf area index by correcting for soil moisture, Remote Sensing of Environment, 29, 25-37.

Daughtry C.S.T., Gallo K.P., Gow ard S.N., Prince S.D., Kustas W.P., 1992, Spectral estimates of absorbed radiation and phytomass production in corn and soybean canopies, Remote Sensing of Environment, 39, 141-152.

Dąbrowska-Zielińska K., Kogan F., Ciołkosz A., Gruszczyńska M., Kowalik W., 2002, Modelling of crop growth condition s and crop yield in Poland using AVHRR-based indices, International Journal of Remote Sensing, Vol. 23, No. 6, 1109-1123.

Dąbrowska-Zielińska K, 1995, Szacowanie ewapotranspiracji, wilgotności gleb i masy zielonej łąk na podstawie zdjęć satelitarnych NOAA [Estimation of evapotranspiration, soil moisture and green biomass of grasslands using NOAA satellite images; in Polish], Prace Geograficzne, nr 165, pp. 81.

Eklundh L., Harrie L., Kuusk A., 2001, Investigating relationships between Landsat ETM+ sensor data and leaf area index in a boreal conifer forest, Remote Sensing of Environment, 78, 239-251.

Gamon J. A., Peñuelas J., Field C.V., 1992, A narrow-waveband spectral index that tracks diurnal changes in photosynthetic efficiency, Remote Sensing of Environment, 4, $35-44$.

Gausman H.W., 1974, Leaf reflectance of near-infrared, Photogrammetric Engineering, 41:183-191.

Goel N.S., 1988, Models of vegetation canopy reflectance and their use in estimation of biophysical parameters from reflectance data, Remote Sensing Reviews, 4, 1-222.

Goel N.S., Thom p son R.L., 2000, A snapshot of canopy reflectance models, and a universal model for radiation regime, Remote Sensing Reviews.

Goel N.S., Q in W., 1994, Influences on canopy architecture on relationships between various vegetation indices and LAI and FPAR: a computer simulation, Remote Sensing Reviews, $10,309-347$.

Griend A.A. van de, Owne M., 1993. On the relationship between thermal emissivity and the normalized difference vegetation index for natural surfaces, International Journal of Remote Sensing, Vol. 14, No. 6, 1119-1131. 
Gruszczyńska M., 1992, Pomiary użytków zielonych systemem LAI i ich zastosowanie [Measurements of grasslands using LAI system and its application; in Polish], Wiad. Melior., No 3., 114-115.

Guyot G., Baret F., Jac que moud S., 1992, Imaging spectroscopy for vegetation studies, [in:] Fundamentals and Prospective Applications, edited by F. Toselli and J. Bodechtel, Kluwer Academic, 145-165.

Heute A.R., 1988, A soil-adjusted vegetation index (SAVI), Remote Sensing of Environment, 25 (3), 295-309.

Jackson R.D., Idso S.B., Reginato R.J., 1977. Wheat canopy temperature: a practical tool for evaluating water requirements, Water Resour. Res, Vol. 13, No 6, 651-656.

Jacks on R.D., 1985, Evaluating evapotranspiration at local and regional scales, Proceedings of the I.E.E., 1086-1096.

Jackson R.D., Moran M.S., Gay L.W., Raymond L.H., 1987. Evaluating evapotranspiration from field crops using airborne radiometry and ground based meteorological data, Irrigation Sci., Vol. 8, No 2, 81-90.

Jacquemoud S., Ustin S., Verdebout J., Schmuck G., Andreoli G., Hosgood B., 1996, Estimating leaf biochemistry using the PROSPECT leaf optical properties model, Remote Sensing of Environment, 56, 194-202.

Jakomulska A., 1999, Przystosowania a spektralna charakterystyka gatunków wysokogórskich: Juncus trifidus, Luzula spadicea i Calamagrostis villosa. Oszacowanie możliwości zdalnej identyfikacji roślinności wysokogórskiej [Adaptation and spectral characteristics of alpine species: Juncus trifidus, Luzula spadicea and Calamagrostis villosa. Assessment possibilities of remote identification of alpine vegetation; in Polish], [in:] Kotarba A., Kozłowska A. (eds.), Prace Geograficzne, nr 174, Badania geoekologiczne $w$ otoczeniu Kasprowego Wierchu [Geoecological research in the Kasprowy Wierch area; in Polish], Wrocław.

Jakomulska A., 1998, Kartowanie wysokogórskiej roślinności Tatr metodami teledetekcji i fizjologii roślin [Vegetation mapping in the Tatra Mountains using remote sensing and plant physiology methods; in Polish], Fotointerpretacja w Geografii. Problemy Telegeoinformacji, T. 26, PTG KTŚ, Warszawa.

Klajnert Z., 1982, Rzeźba [Relief; in Polish], [in:] Województwo skierniewickie. Monografia regionalna [Skierniewice Voivodship. Regional Monography; in Polish], Łódź - Skierniewice.

Knipling E.B., 1970, Physical and physiological basis for the reflectance of visible and nearinfrared radiation from vegetation, Remote Sensing of Environment, 1: 155-159.

Kondracki J., 1978, Geografia fizyczna Polski [Physical Geography of Poland], PWN, Warszawa.

Koziejowa U., Koziej L., 1996, Geomorfologia. Gleby. Topo- i bioklimat [Geomorphology. Soils. Topo- and bioclimate; in Polish], [in:] Król B. (ed), Plan Ochrony BPK. Środowisko abiotyczne [Protection Plan of Bolimowski Landscape Park; in Polish], Urząd Wojewódzki w Skierniewicach, Skierniewice.

Kucharski L., 1995, Rezerwat takowo - torfowiskowy „Polana Siwica” [Meadow-peat reserve „Siwica Glade”; in Polish], dok. projekt. Urząd Wojewódzki w Skierniewicach, Skierniewice.

Kucharski L., 1999, Szata roślinna Łak Polski Środkowej i jej zmiany $w$ XX stuleciu [Vegetation of Middle Poland Meadows and its changes in XX ${ }^{\text {th }}$ century; in Polish], Uniwersytet Łódzki. Łódź.

Kucharski L., Pis arek W., 1997, Polany Puszczy Bolimowskiej [Glades of Bolimow Forest; in Polish], Dyrekcja Bolimowskiego Parku Krajobrazowego, Skierniewice.

Kurnatowska A., 1999, Large scale vegetation mapping in mountain environments using remote sensing and plant physiology methods, Proceedings of EARSeL/NSEOG Symposium: Operational Remote Sensing for Sustainable Development (11-14 maj, 1998, Enschede).

Loveland T.R., Merchant J.W., Ohlen D.O., Brown J.F., 1991, Development of a land cover characteristics database for the conterminous U.S., Photogrammetric Engineering and Remote Sensing, 57, 1453-1463.

Maas S.J., Dunlap J.R., 1989, Reflectance, transmittance, and absorptance of light by normal, etiolated, and albino corn leaves, Agron. Journal, 81:105-110. 
Misiewicz-Śnieszko Ł., 1982. Klimat [Climate: in Polish], [in:] Województwo skierniewickie, Monografia regionalna [Skierniewice Voivodship. Regional Monography; in Polish], Łódź - Skierniewice.

Myneni R.B., Nemani R.R., Running S.W., 1997, Estimation of global leaf area indes and absorbed PAR using radiative transfer models, IEEE Transactions on Geoscience and Remote Sensing, 35, 1380-1393.

Myneni R.B., Ross J., 1990, Photon-Vegetation Interactions. Applications in Optical Remote Sensing and Plant Ecology, Springer-Verlag.

Myneni R.B., Ross J., Asrar F., 1989, A review on the theory of photon transport in leaf canopies, Agricultural and Forest Meteorology, 45, 1-153.

North P.R.J., 2002, Estimation of fAPAR, LAI, and vegetation fractional cover from ATSR-2 imagery, Remote Sensing of Environment, 80, 114-121

Olaczek R., 1999. Puszcza Bolimowska - przeszłość i przyszłość [Bolimow Forest - past and future; in Polish], [in:] Czyżewska K., (ed.) Roślinność Bolimowskiego Parku Krajobrazowego [Vegetation of Bolimow Landscape park; in Polish], Monographiae Botanicae, Łódź

Plu m mer S.E., North P.R.J., Brigg s S.A., 1994, The Angular Vegetation Index: an atmospherically resistant index for the second along track scanning radiometer (ATSR-2), Proceedings of the 6th Symposium on Physical Measurements and Spectral Signatures in Remote Sensing CNES, Toulouse, 717-722.

Purevdorj Ts., Rateishi R., Ishiyama T., Honda Y., 1998, Relationships between percent vegetation cover and vegetation indices, International Journal of Remote Sensing, Vol. 19, No. 18, 3519-3535.

Qi J., Chehbouni A., Heute A.R., Kerr Y.H., Sorooshian S., 1994, A modified soil adjusted vegetation Index, Remote Sensing of Environment, 48 (2), 119-126.

Rataj M., 1998, Instrukcja obstugi spektrometru SP-1 [Operational manual of SP-1 spectrometer; in Polish], Remote Sensing Department, Space Research Centre, Polish Academy of Sciences, Warsaw.

Rataj M., 1999, Metody teledetekcyjne. Instruktaż radiometryczny. Zintegrowane techniki pomiarowe - Teledetekcja. Materiały dla studentów Międzywydziałowych Studiów Ochrony Środowiska Uniwersytetu Warszawskiego [Remote sensing methods. Radiometric instructions. Integrated measurement techniques - remote sensing. Guide for students of the Interfaculty Studies of Environmental Protection, Warsaw University; in Polish], Szymbark.

Sellers P.J., Los S.O., Tucker C.J., Justice C.O., Dazlich D.A., Collatz G.J., R andall D.A., 1996, A revised land surface parameterization (SiB2) for atmospheric GCMs Part II: The generation of global fields of terrestrial biophysical parameters from satellite data, Journal of Climate, 9, 706-737.

Traut A., 2000, Waloryzacja przyrodnicza i projekt ochrony tak w Puszczy Bolimowskiej [Environmental valorisation and meadows protection in Bolimow Forest; in Polish], Mnsc. Uniwersytet Łódzki, Łódź.

Trime ${ }^{\circledR}$ Measuring Moisture Theory, 26.06.1997. Physics Consulting ${ }^{\text {TM }}$. DMP AG. http:// www.dmp.ch/Trime Theory/ki/Date 26.06.97/Rev. 11.07.99.

Tucker C.J., 1979, Red and photographic infrared linear combinations for monitoring vegetation, Remote Sensing of the Environment, 8, 127-150.

Welle s J.M., 1990, Some Indirect Methods of Estimating Canopy Structure, Remote Sensing Reviews, Vol. (5)1, 31-43.

Welle s J.M., N or m a n J.M., 1991. Measurement of canopy architecture, Agronomy Journal, Vol. 83 , No. 5 .

Woolley J.T., 1971, Reflectance and transmittance of light by leaves, Plant Physiology, 47:656-662.

Zagajewski B., 2000, Remote sensing measurements of lead concentrations in plants, [in:] Miscellanea Geographica, Vol. 9, Faculty of Geography and Regional Studies, Warsaw University, Warsaw, 267-280. 